DOI: 10.2478/rae-2021-0020 Review of Artistic Education no. 212021 164-170

\title{
2. PERFORMANCE IN SPORTS AND ART. THE BEGINNINGS
}

\author{
Ana-Cristina Leșe $\mathrm{e}^{170}$ \\ Raluca Minea ${ }^{171}$ \\ Adina Ioana Armencia ${ }^{172}$
}

\begin{abstract}
Performance or show is one of the phenomena that characterizes our society since antiquity to nowadays and we make reference to: theater, music, sports, politics and more. We will approach performance also in sports and art, because this word has its origin in this area. According to the explanatory dictionary, performance represents a set of elements, things, facts which recall our attention, make an impression and provoke reactions. A show can surprise, intrigue, monopolizes and creates a kind of beneficial addiction. And this can only be in favor of a society in a constant search for "strong" sensations. A show in the field of sports or art is a good attempt to direct the spectators towards a better perception of reality. The involvement of society as for creation and continuous development of the phenomenon called "show" reveals people's need for palpable human and beautiful sensations.
\end{abstract}

Key words: entertainment, art, sports

\section{Introduction}

The common element of these two fields of sports and art is represented by performance. In ancient times these two areas were difficult to separate, so that one determined the other. Shows or dramatic performances, tragedies and comedies were born in Greece, in the middle of the $6^{\text {th }}$ century B.C. which had religious themes related to god Dionysus. Athenian spectators were passionate about theatrical performances. This sensory phenomenon of perceiving performances persists even today in all types of events that can fit into the conditions of a show. Viewers go through different emotional states of pleasure, anger, fear or emotion that create a certain addiction. Having such a strong impact on people's daily lives, many representations are immortalized in murals, paintings, sculptures that have become authentic masterpieces over time. We can state that ancient representations are a real source of inspiration for art of all times.

Sports performance generally gathers a large audience around it, either due to the element of competitiveness where supporters intervene, or due to the physical actions used which are easy to appreciate and which catch attention due to suppleness, brutality or agility. What is certain is that people have been careful not to miss performance in their daily lives at any period of time. Each period of time has left its mark on the characteristics of a performance from sports or art field. There are, for instance, figure skating performances associated with a musical or theatrical show. The collaboration between these types of artistic events

\footnotetext{
170 Associate Professor PhD., "George Enescu" National University of Arts from Iaşi, Romania, email: analese2000@yahoo.com

171 Lecturer PhD., "George Enescu" National University of Arts from Iaşi, Romania, email: ralucaminea.74@gmail.com

172 Lecturer PhD., „Grigore T. Popa” University of Medicine and Pharmacy from Iaşi, România, email: oanaarmencia@yahoo.com
} 
increases the degree of appreciation, of beauty and can be considered a real show. This is not something new if we remember that at the beginning of the first Olympic Games in 776 B.C., in Olympia, took place several activities like: a solemn procession, sacrifices in honor of Zeus, a parade of music competitors and also the Olympic oath.

\section{Performance in ancient works}

The first representations of some sports activities proceeds from prehistory, but sports show dates from Antiquity, in Greek civilization. However, there is evidence of sports show in ancient Egypt, but it's associated with the theme of military campaigns since the Old Empire

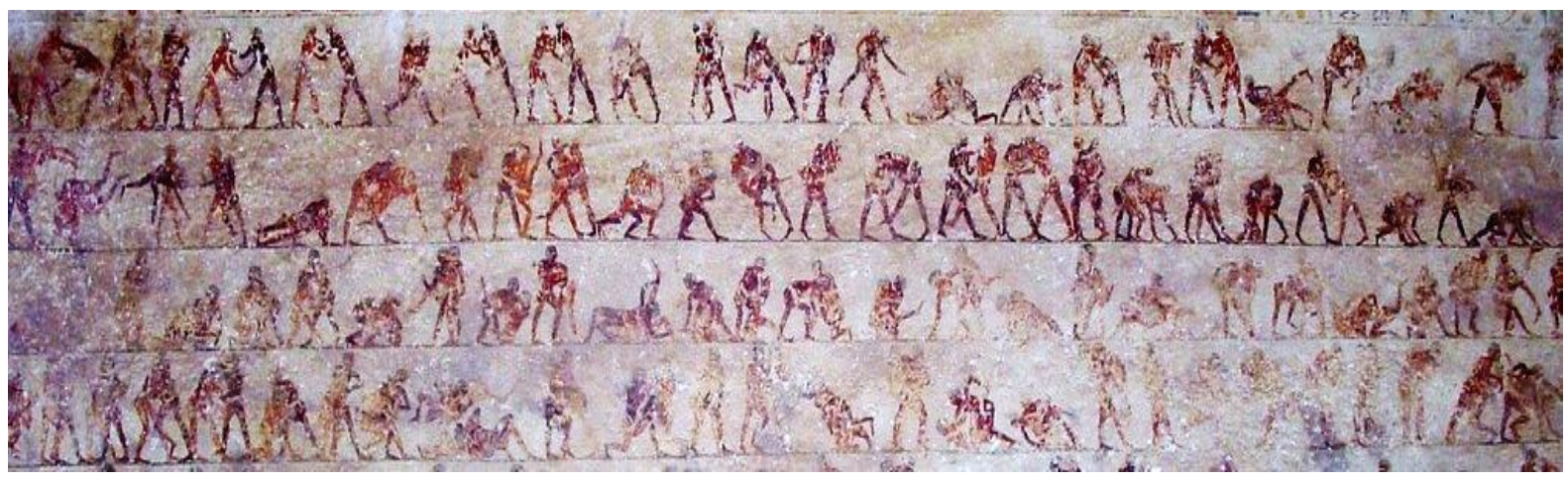

Fig. 1. Fight sports scenes, paramilitary training of young people, mural painting during the New Kingdom, $19^{\text {th }}$ century B.C., Beni Hassan, Egypt.

Sports show is also associated with hunting, as one can notice in the Cretan frescoes. The fights with bulls are animated, full of vitality and the human silhouettes are more adequate to the scenographic intention than to the anatomical realism ${ }^{173}$. At the beginning sports games and competitions, such as bullfighting (different from those known today in Spain or Mexico), were opportunities for spectacular gymnastics and acrobatics exercises.

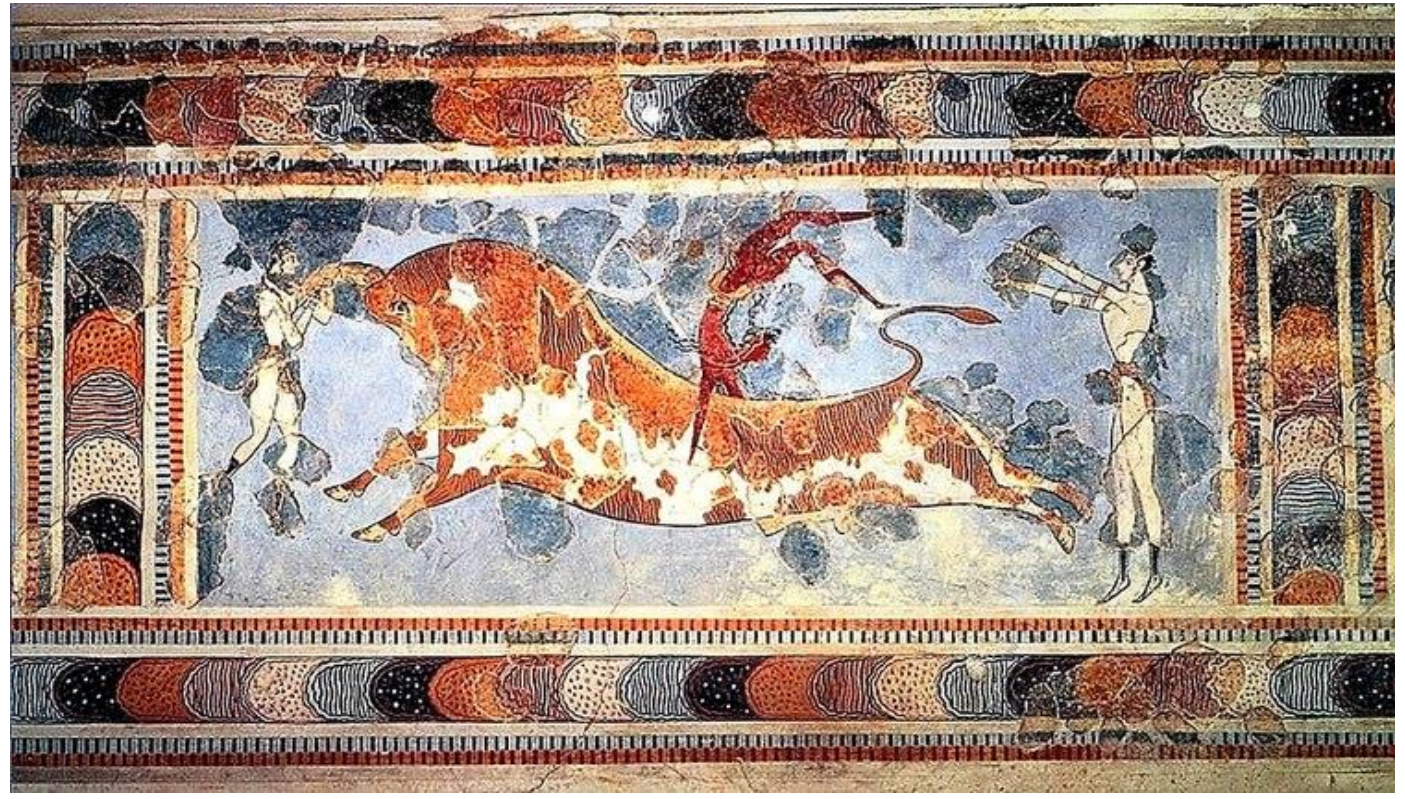

Fig. 2. Game with bulls, Cnossos, $15^{\text {th }}$ century B.C.

${ }^{173}$ T. Vlad, Perfecţiunea viului, Ed. Artes, Iaşi, 2012, p.14 


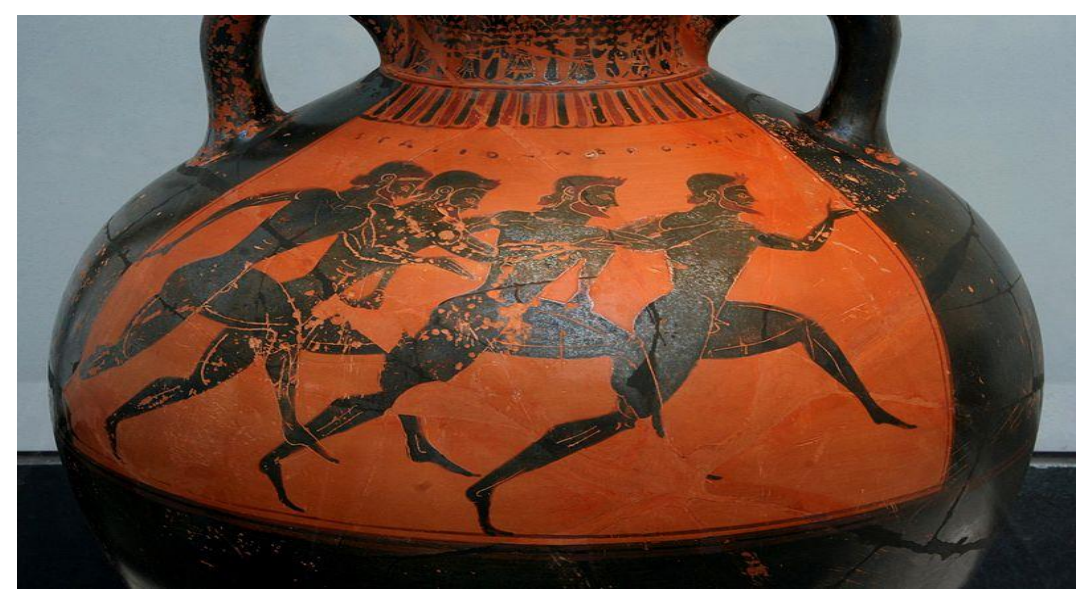

Fig. 3. Greek vase with runners at the panathenaic games, 530 B.C.

The Corinthian style developed in Arcadia in $5^{\text {th }}$ century B.C. and derived from the Ionic style and in this context sculpture also evolved, being close to sports and fight arena. Gymnastics and athletics sports in general provided artists with models of inspiration and study of the human body ${ }^{174}$. The Olympic Games, whose beginning was marked by an imposing religious procession, lasted for five days, during which in addition to sports competitions, several sacrifices were made for the gods of the Greek Pantheon. The whole show had a sacred significance which was also proved by the sacred peace or ekecheiria ${ }^{175}$ which was a period when the Greek cities were forbidden to engage in any kind of armed conflict ${ }^{176}$. Born almost 3,000 years ago on Mount Olympus, the Olympics Games have always been a symbol of the highest human virtues.
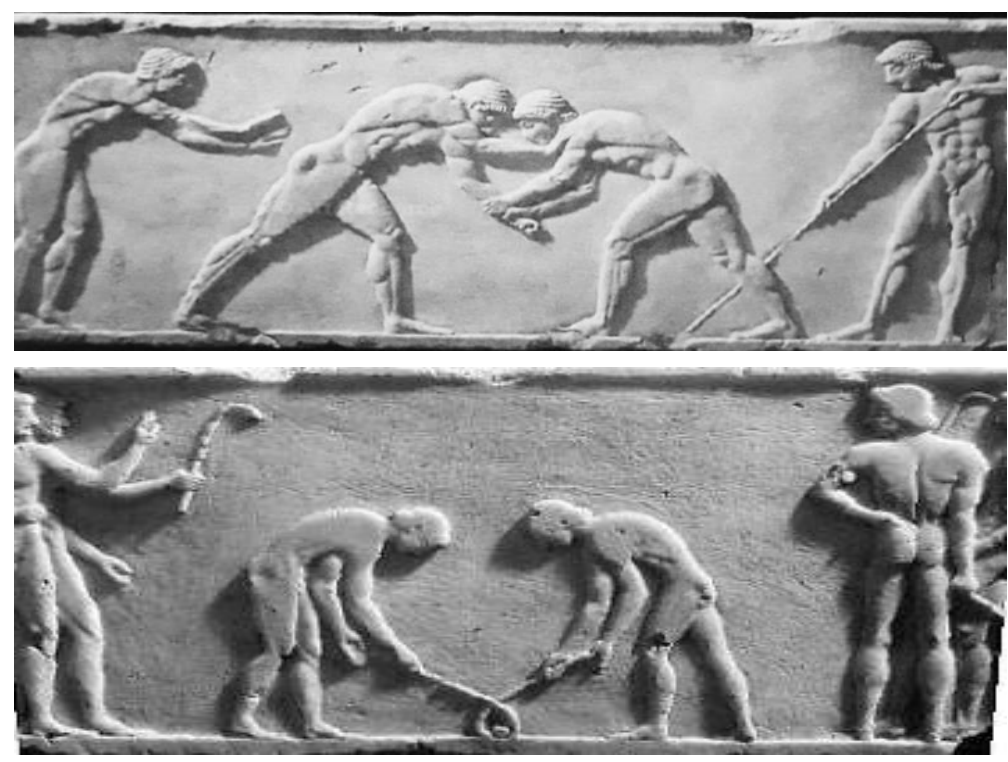

Fig. 4. Greek civilization, Plinth of kouros statue, bas-relief depicting boxers and players with sticks and ball, known as "Hockey players", circa 490 B.C. from Kerameikos Necropolis in Athens, Greece.

\footnotetext{
${ }^{174}$ X. Barral I Altet, Istoria Artei, trad. Răzvan Junescu, Ed. Meridiane, Bucureşti, 2002, p. 40

175 ,the spirit and personification of truce, armistice, and cessation of hostilities” apud Pausanias, Description of Greece 5. 10. 10; 5. 26. 2

176 https://www.historia.ro/sectiune/general/articol/istoria-jocurilor-olimpice
} 
On the occasion of the Panathenaic Festival, a celebration in honor of Goddess Athens which takes place every four years, the winners of the competition were offered amphorae decorated with goddess face and athletes in that action. Greeks practiced nude sports, providing artists with models for their study. Competitors could come from any social class and athletes who couldn't afford a private coach were supported by the fortress which provided them with the necessary financial support for training. At the beginning games were open only to Greek speakers and practised by the competitors from all Mediterranean or Black Sea colonies.

Reliefs with athletes represented in gyms or during their training in arena, such as the relief with four ephebes participating in fighting exercises, are a good opportunity to show the beauty of healthy and robust bodies. The archaic artist has an objective vision about the confrontation scene that takes place according to strict rules and fair play. Figure no. 4 highlights the athletes's concentration to keep their balance. There are differences between the two images in the way the characters were represented: while the boxers have a strong musculature, the two hockey players have a flat body modeling. Since Romans adopted the Olympic Games, they acquired an universal character and among the competitors, besides the Latin athletes, there is mentioned in history even an Armenian king ${ }^{177}$. The competitors' noble spirit remained alive and perpetuated in a global competition.

UnlikeGreeks, who loved all sports, Romans practiced mainly swimming and various ball games and spent their free time with games of chance, such as dice. The most common entertainment opportunities were public performances and games. Theater performances had in the beginning a religious character which disappeared over time. The first permanent Roman theater was built by Pompeius in the $1^{\text {st }}$ century B.C. and had a capacity of 40.000 seats. Unlike the Greek one, which used natural slopes to place spectators in the amphitheater, the Roman theater was entirely built and had a semicircular free space in front of the stage and a wall in the background which was a permanent decoration. Theatrical performances accompanied by flute music were organized by a magistrate. The first play by a Latin author is attributed to Livius Andronicus in the $3^{\text {rd }}$ century B.C. ${ }^{178}$.

\section{Sports show}

Sports show seems to be nowadays an extension of the ancient performances which are always subject to conditions of improvement and exceed their own psycho-physical limits in accordance, of course, with the social order. One can admit that sport is an integral part of the culture of a civilization, which is present in the cultural memory through artists', chroniclers', or poets' contribution. Among the blood sports of the ancient world, such as: gladiator fights, bull-leaping or deadly competitions, there are also: ball games, swimming, horseback riding, running and various types of physical exercises that Plato valued

\footnotetext{
177 https://www.historia.ro/sectiune/general/articol/istoria-jocurilor-olimpice

178 http://istorieovidius.weebly.com/uploads/5/6/6/9/5669765/28559582-arte-si-civilizatii-civilizatia-cultura-si-artagreaca.pdf 
in harmony with proportions, beauty and human health and Cicero saw a human's beauty in the movement and attitude of the body. The first games from Olympia, Greece, in 776 B.C., played a decisive role in sports show and were known afterwards as Olympic Games that took place every four years during the holidays of Zeus, between different cities of ancient Greece.

"The magistrates called Helladonike organized the games, judged the results and awarded prizes. The games lasted for five days and began with a solemn procession and sacrifices, with the parade of competitors and with the Olympic oath. In the second day there was a competition for young people aged 18-20 and in the third day took place activities like: running, fights, boxing and fight competitions. The most contested event which was the pentathlon took place in the fourth day, followed by the competitions of "hoplitodromos" (armed people), running carriage and horse racing. Over time, the order of the competitions has changed countless times. In the fifth day the winners (Olimpionike, winner of Olympia) were awarded with a wreath of wild olive branches. Those who retained the title of champion in several successive editions or were winners of several games which took place in Greece were called periodonikes" ${ }^{179}$.

This sports show took place until 393 when Emperor Theodosius I banned the Olympic Games. But the show must go on! In 1896 Pierre Fredy, Baron de Coubertin, was fascinated by ancient Greece and the ideal of movement (in the sense of gymnastics / sports) and pleaded firmly for the relaunch of the ancient Olympic Games in a modern version. Thus the first modern Olympic Games started taking place again where elsewhere than in Greece, on the restored stadium called Panatinaiko. The first edition was attended by 14 countries and 241 athletes who competed in 43 events included in 9 sports.

G. Magnane quoted by Cârstea Gh., (1990) considers that the "emotional symbiosis" between athletes and spectators is an essential, distinctive feature of the sports show, as the supporters have a special role as for organising sports shows. A sports show or an artistic one must provide a specific emotional framework in order to impress the spectators in a positive way and to create a symbiosis. The show is part of any generation's life. Sports events are part of social festivities with important therapeutic functions, from an aesthetic and psycho-physical point of view. The spectators / supporters identify with the winners or the losers, going through the specific emotional states generated by the moments of the show."From the moment sport was set up as a show, it began to look more and more like theater. Although it had more rigorously observed acts (rounds), sport is characterized by improvisation and unpredictability. Camil Petrescu in his essay called "Sport and theater" discusses this parallel between sport and theater, concluding that: "In sport everything is becoming. No one can predict anything. The story is unique. It doesn't follow the instructions of a text"180.

\footnotetext{
179 https://ro.wikipedia.org/wiki/Jocurile_Olimpice_antice

${ }^{180}$ Denisa Elena Petrehuş, SPORT AS A FORM OF ENTERTAINMENT, Arhipelag XXI Press, Tîrgu Mureș, 2017, e-ISBN: 978-606-8624-01-3
} 


\section{The impact of the show upon society}

Show or performance means a set of elements, things, facts that catch our attention, that impress and provoke reactions ${ }^{181}$. This explains the large number of spectators who participate for various reasons like:

- improving the general culture

- appreciation of works, people, actions

- supporting teams, athletes

- spending free time

- delight and relaxation

- development of aesthetic sense

- development of artistic / sports education

- takes into account the style, time and specificity of the society.

Live performances, whether we refer to the field of art or sports, have a strong impact on the individual emotional behavior. Henry Dupont argues that emotions with their multiple forms are not innate, but socially constructed as components of the personality created by individuals as a result of interactions with the other people, with activities or actions carried out or encountered during their process of development. Feelings and emotions are constructions characterised by needs and values which change considerably during development ${ }^{182}$. Show can also be a component that regulates energy and emotion, as an action of a need to satisfy / to meet specific needs. Spectators face sometimes an unreal world which is different from the pulse of everyday life, in which they find usual sequences in a theatrical, musical, literary, sports or visual language that can create decisions and precepts for personal life.

The world created by the presence of a show is in a revolutionary expansion, without limits, but is distinct at the same time, offering a lifestyle and a culture to the society. The protagonists of a show can be actors, musicians, dancers, athletes, etc., professionals dedicated to creating a world surrounded by beauty and sensitivity. Starting from their innate talent and continuing with hard work, artists / athletes aim to appear in front of a public in order to represent an avant-garde movement or to be in a continuous self-transcendence.

\section{Conclusions}

First of all, taking into account that the digital age has monopolised a large part of the young generation, one can consider that show mustn't give up its specificity. Show has been a component of human life in society since antiquity. Consumers of sports or artistic entertainment will continue to be present in each generation. Secondly, a show must always offer something new, attractive and educational. This is its continuity over time. Third, we spectators learn to appreciate the work of show - creators. The relationship between a show and the spectators must be a symbiosis that will leave its mark on our times and provide models for future. There is no show without spectators.

${ }^{181}$ https://ro.wiktionary.org/wiki/spectacol\#Etimologie

${ }^{182}$ M. R. Thomas, Recent theories of human development, Sage Publications, 2001 


\section{References}

\section{Books}

1. M. R. Thomas, 2001, Recent theories of human development, Sage Publications

2. T. Vlad, 2012, Perfecţiunea viului, Artes Publishing House, p.14, Iaşi

3. X. Barral I Altet, 2002, Istoria Artei, translator Răzvan Junescu, Meridiane Publishing House, p. 40, Bucureşti

\section{Articles}

1. Denisa Elena Petrehuș, 2017, SPORT AS A FORM OF ENTERTAINMENT, Arhipelag XXI Press, e-ISBN: 978-606-8624-01-3, Tîrgu Mureș

2 .,the spirit and personification of truce, armistice, and cessation of hostilities" apud Pausanias, Description of Greece 5. 10. 10; 5. 26. 2.

\section{Websites}

1. https://www.historia.ro/sectiune/general/articol/istoria-jocurilor-olimpice

2. http://istorieovidius.weebly.com/uploads/5/6/6/9/5669765/28559582-arte-sicivilizatii-civilizatia-cultura-si-arta-greaca.pdf

3. https://ro.wiktionary.org/wiki/spectacol\#Etimologie

4. https://ro.wikipedia.org/wiki/Jocurile_Olimpice_antice

5. https://dexonline.ro/definitie/spectacol 